\title{
Comparatives Study of Soil Organic Carbon (SOC) under Forest, Cultivated and Barren Land: A Case of Chovar Village, Kathmandu
}

\author{
S. Bhandari ${ }^{1}$ and S. Bam ${ }^{2}$ \\ ${ }^{1}$ Central Department of Environmental Science, Tribhuvan University, Kathmandu \\ ${ }^{2}$ Amrit Campus, Tribhuvan University, Kathmandu \\ e-mail: chhetri.suresh02@gmail.com
}

\begin{abstract}
The study was carried out in Chovar village of Kritipur Municipality, Kathmandu to compare the soil organic carbon (SOC) of three main land use types namely forest, agricultural and barren land and to show how land use and management are among the most important determinants of SOC stock. Stratified random sampling method was used for collecting soil samples. Walkley and Black method was applied for measuring SOC. Land use and soil depth both affected SOC stock significantly. Forest soil had higher SOC stock ( $98 \mathrm{t} \mathrm{ha}^{-1}$ ) as compared to agricultural land with $36.6 \mathrm{t} \mathrm{ha}^{-1}$ and barren land with $83.6 \mathrm{t} \mathrm{ha}^{-1}$. Similarly, the SOC in terms of $\mathrm{CO}_{2}$ equivalents for forest, agricultural and barren land ranged from 183.5 to $80.74 \mathrm{CO}_{2}$-e ha-1, 79.27 to $22.02 \mathrm{CO}_{2}$-e ha-1 and 121.11 to $80.74 \mathrm{CO}_{2}$-e ha-1 for 0$20 \mathrm{~cm}$ to 40-60 cm soil depth, respectively. Bulk density (BD) was found less in forest soil compared to other lands at all depths, which showed negative correlation with SOC. The study showed a dire need to increase current soil $\mathrm{C}$ stocks which can be achieved through improvements in land use and management practices, particularly through conservation and restoration of degraded forests and soils.
\end{abstract}

Key words: Chovar, land use, management practices, soil organic carbon (SOC)

\section{Introduction}

Carbon sequestration is the long term storage of carbon in oceans, soils, vegetation (especially forests), and geologic formations. Instead of being a carbon source, soils could be transformed into carbon sinks, absorbing carbon instead of emitting it. Soil carbon is an important part of terrestrial carbon pool and soils of the world are potentially viable sinks for atmospheric carbon (Lal et al. 1998 and Bajracharya et al. 1998). Carbon sequestration in soils is a climate change-mitigating strategy, based on the assumption that movement, or flux, of carbon from the air to the soil can be increased while the release of carbon from the soil back to the atmosphere is decreased. This has potential to reduce atmospheric $\mathrm{CO}_{2}$, thereby slowing global warming and mitigating climate change. One possible mechanism for mitigating $\mathrm{CO}_{2}$ emission is therefore its sequestration, or redistribution from air to soils, terrestrial biomass, geologic formations, and the oceans. Carbon sequestration can be appropriate from both an environmental and a socioeconomic point of view. The environmental perspective includes removal of $\mathrm{CO}_{2}$ from the atmosphere, improvement of soil quality, and increase in biodiversity (Batjes \& Sombroek 1997). Therefore, soils play a major role in maintaining a balanced global carbon cycle.

Soil store $1.5 * 10^{18} \mathrm{~g}$ of organic carbon (C) globally about twice as much $\mathrm{C}$ as found in the atmosphere and three times the quantity contained in terrestrial vegetation (Schlesinger 1997). Soil can be a source or a sink of atmospheric $\mathrm{C}$ depending upon land use and management. Land use and vegetation type influence soil erosion and $\mathrm{C}$ dynamics through its effect on SOC contents, $\mathrm{CO}_{2}$ flux and dissolved organic carbon (DOC) leaching from soil (Bajracharaya et al. 1998). Land management that exerts the least soil disturbance contributes to increased SOC accumulation, while intensive disturbance results in lower SOC and consequent soil degradation. Land use change from native ecosystem to cultivated ecosystem causes losses of soil carbon. Gradual conversion of forest and grassland to cropland has resulted in significant 
losses of soil carbon worldwide. These stocks are dynamic, depending upon various factors and processes operating in the systems, the most significant being land use, land use change, soil erosion and deforestation (IPCC 2000).

Soil is deteriorating at an alarming rate in developing countries like Nepal due to land use changes (IPCC 2000), lowering $C$ sequestration. In this context, there is dire need to conduct researchs related to $\mathrm{C}$ pools and C sequestration (Metting et al. 1998 and Lal 2001) among different land uses. A considerable number of studies have been conducted in industrialised countries addressing these issues, however, comparatively few studies have been conducted in developing countries, especially South Asia. Therefore, this study aims to establish the base line information for carbon sequestration potential of soil. The finding of research gives the amount of carbon in soil and its contribution in carbon sequestration. The study aims to provide information on the distribution and status of SOC among different land uses.

\section{Methodology}

\section{Study area}

This work was carried out during February 2011 to July 2011 in Chovar village of Kirtipur municipality. It is located $8 \mathrm{~km}$ southwest of the capital city, Kathmandu. This area lies on top of a hill with an average elevation of $1342 \mathrm{~m}$ above the mean sea level. The latitude is $27^{\circ} 39^{\prime} 27^{\prime \prime} \mathrm{N}$ and longitude is $85^{\circ} 17^{\prime} 21^{\prime \prime}$ E. It has an area of $0.54 \mathrm{~km}^{2}$. It lies in subtropical region with characteristic monsoon rainfall and three distinct seasons: hot and dry summer (February to May), hot and moist rainy season (June to September) and cold and dry winter (October to January). Maximum temperature ranges from $30^{\circ}$ to $33^{\circ} \mathrm{C}$ in summer and minimum temperature ranges from $-3^{\circ}$ to $0^{\circ} \mathrm{C}$ in winter. The whole area can be divided into three main land use type; pine forest along the east direction down slope, cultivated land uphill and barren rocky land south west with limestone composition. Soil in this area, in majority, is silty loam.

\section{Data collection}

Sampling design: The stratified random sampling was used, where the area was divided into different strata based on prior knowledge of land use types. Ten samples from each strata were collected from the major three land use types, namely forest, agricultural and barren land.

Soil sampling: For carbon stock, soil was dug at each sampling site to $60 \mathrm{~cm}$ depth. Soil samples at different depths $(0-20 \mathrm{~cm}, 20-40 \mathrm{~cm}$ and $40-60 \mathrm{~cm})$ were taken using a soil auger. For bulk density, samples were taken with the help of a core ring sampler of $427.6 \mathrm{~cm}^{3}$ volume at $10 \mathrm{~cm}, 30 \mathrm{~cm}$ and $50 \mathrm{~cm}$ depths. The fresh soil extracted by soil corer was bagged in plastic bags, sealed, labelled and transported to the laboratory for determining oven dry weight.

Organic matter in soil: Organic matter content in the soil samples was measured using a Walkley-Black Wet Oxidation method described by Walkley and Black (1934).

\section{Data analysis}

Conversion factor for organic matter (\%) to organic carbon (\%): Organic matter (\%) converted into organic carbon (\%) by using the formula below:

Organic carbon $(\%)=\underline{58 \times \text { Organic matter }(\%)}$ 100

Soil organic carbon (SOC): Total soil organic carbon was calculated by using the formula given below (Pearson et al. 2007):

SOC $(\mathrm{t} / \mathrm{ha})=[($ Organic carbon content $\% \times$ soil bulk density $\left(\mathrm{gm} / \mathrm{cm}^{3}\right) \times$ thickness of horizon $\left.(\mathrm{cm})\right] \times 100$

Bulk density (BD): Soil BD was determined using core sampling method (Blake and Hartege 1986). The oven dried (at $105^{\circ} \mathrm{C}$ temp) soil samples were used for moisture correction. The dried soils were sieved through a $2 \mathrm{~mm}$ sieve and weighed the weight of stones was recorded for stone correction. The following formula was used to calculate the bulk density using stone correction (Pearson et al. 2005).

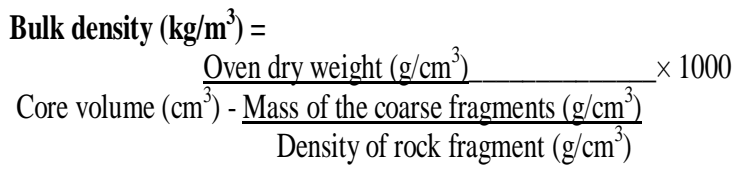
$\times 1000$

Where, the coarse fragments were $>2 \mathrm{~mm}$. The density of rock fragments was $2.65 \mathrm{~g} / \mathrm{cm}^{3}$.

Correlation between SOC and BD: It was determined as Pearson correlation. Effect of land use on SOC and 
BD was analysed by comparisons of their mean values. Multiple comparisons of mean values for each class variable (among land uses, depths, SOC and BD) were carried out using Addin software XLSTAT in Microsoft Excel 2007.

Mean total carbon stock: Here, the mean total soil organic carbon of each land use type was determined by summation of mean SOC for all three horizons.

$$
M T_{S O C}=\sum_{h=1}^{3} S O C_{(\text {mean })}
$$

Where:

$$
\begin{array}{ll}
M T_{\text {SOC }} & \text { Mean total carbon stock, } \mathrm{tha}^{-1} \\
S O C_{(\text {mean })} & \text { Mean soil organic carbon, } \mathrm{t} \mathrm{ha}^{-1} \\
h & \text { No. of soil horizons (i.e. } 1=0-20 \mathrm{~cm}, 2 \\
& =20-40 \mathrm{~cm} \text { and } 3=40-60 \mathrm{~cm})
\end{array}
$$

Mean SOC in terms of $\mathrm{CO}_{2}$ equivalents per unit area: The following equation was applied to convert the mean SOC to $\mathrm{CO}_{2}$ equivalents per unit area (IPCC 2003):

$$
\mathrm{C}_{\mathrm{soc}}=\operatorname{SOC}_{(\text {mean })} \times \frac{44}{12}
$$

Where:

$$
\begin{array}{ll}
\mathrm{C}_{\mathrm{SOC}} & \text { Mean SOC in terms of } \mathrm{CO}_{2} \text {-e ha-1 } \\
\mathrm{SOC}_{\text {(mean) }} & \text { Mean SOC } \mathrm{tha}^{-1} \\
44 / 12 & \begin{array}{l}
\text { Ratio of molecular weight of } \mathrm{CO}_{2} \text { to } \\
\text { carbon, } \mathrm{CO}_{2}-\mathrm{e} \mathrm{t} \mathrm{C}^{-1}
\end{array}
\end{array}
$$

\section{Results and Discussion}

Bulk density (BD): There was a gradual increase of $\mathrm{BD}$ with the increase in soil depth in case of all three land use types (Table 1). Minimum BD $1 \mathrm{~kg} / \mathrm{m}$ was found at the top soil i.e. at $0-20 \mathrm{~cm}$ in forest and maximum BD $1.4 \mathrm{~kg} / \mathrm{m}$ was found $40-60 \mathrm{~cm}$ depth of the barren land.

Table 1. Bulk density of soil at different depths in different land uses

\begin{tabular}{c|c|c|c|c|c}
\hline SN & Depth (cm) & No. of samples & $\begin{array}{l}\text { Mean BD of } \\
\text { forest land } \\
\left(\mathrm{kg} / \mathrm{m}^{3}\right)\end{array}$ & $\begin{array}{l}\text { Mean BD of } \\
\text { agricultural land } \\
\left(\mathrm{kg} / \mathrm{m}^{3}\right)\end{array}$ & $\begin{array}{l}\text { Mean BD of } \\
\text { Barren land } \\
\left(\mathrm{kg} / \mathrm{m}^{3}\right)\end{array}$ \\
\hline 1. & $0-20$ & 10 & 1 & 1 & 1.1 \\
2. & $20-40$ & 10 & 1 & 1.2 & 1.2 \\
3. & $40-60$ & 10 & 1.1 & 1.2 & 1.4 \\
\hline
\end{tabular}

The top soil had low BD indicating that the soil was good for vegetation growth compared to other soil depths. The bulk density depends on several factors such as compaction, consolidation and amount of SOC present in the soil but is highly correlated to the organic carbon content (Morisada et al. 2004, Liefeld et al. 2005). This may be probably as a result of lower organic contents, less aggregation, fewer roots and other soil dwelling organisms and compaction caused by the weight of the overlying layers (Brady 1999).

Soil organic carbon: The soil organic carbon in forest depends upon the forest type, climate, moisture, temperature and types of soil. Organic matter in the study area was determined depth wise at every site. Depthwise SOC results are mentioned in Fig. 1. A decreasing trend in soil organic carbon was seen, which ranged from $50 \mathrm{tha}^{-1}$ to $22 \mathrm{tha}^{-1}$ for the depth 0 $20 \mathrm{~cm}$ to $40-60 \mathrm{~cm}$. The trend was the same for agricultural and barren land, where SOC values decreased with increasing depths, and ranged from $21.6 \mathrm{t} \mathrm{ha}^{-1}$ to $6 \mathrm{t} \mathrm{ha}^{-1}$ and $33 \mathrm{t} \mathrm{ha}^{-1}$ to $22 \mathrm{t} \mathrm{ha}^{-1}$ respectively. This study also shows that SOC was high at top soil due to the presence of vegetation compared to other two soil depths which had no vegetation except roots of the vegetation. SOC is high when there is high amount of biomass present. But it is not only one factor that affects SOC sequestration.

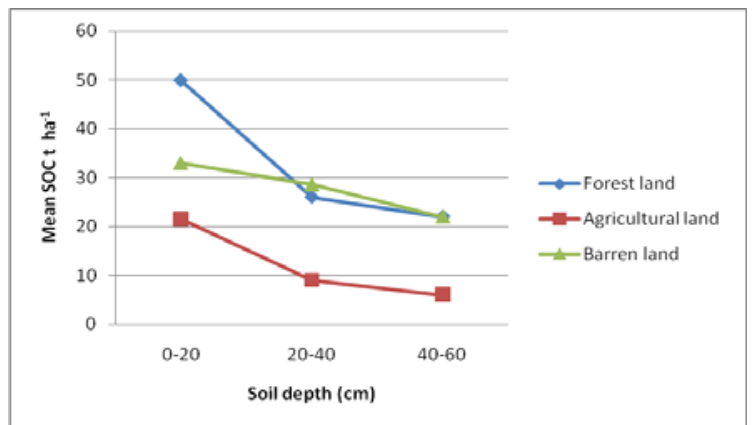

Fig. 1. SOC contents with soil depths under different land uses. 
The value for SOC was lowest in agricultural land. The SOC followed the order as forest $>$ barren land $>$ agricultural land. The barren land showed higher SOC than agricultural land. As we could see agricultural land was highly disturbed with tillage farming and heavy uses of chemical fertilizers whereas the barren land was less disturbed with scruby vegetation. As conventional agricultural system can decrease soil organic carbon (Paustain et al. 1997 and Drinkwater et al. 1998).

Correlation between SOC and BD: SOC is negatively correlated with bulk density. The present study favours this concept i.e. this study found perfect negative correlation between SOC and BD with different land use types. It was also true in all incremental depths except $40-60 \mathrm{~cm}$ where the correlation was positive (Table 2). The rocky nature of soil in study area could have brought such result. The study on the land use effect on soil carbon sequestration in Mardi watershed of Nepal reported the similar result of increasing trend of BD in deeper layer of the soil where SOC showed decreasing trend in such conditions (Shrestha 2002).

Table 2. Correlation between SOC and BD

\begin{tabular}{c|c|c|c}
\hline SN & \multicolumn{2}{|c|}{ Attribute } & $\begin{array}{c}\text { *Correlation } \\
\text { Coefficient }\end{array}$ \\
\hline 1. & Depth & $0-20$ & -0.113 \\
2. & (cm) & $20-40$ & -0.390 \\
3. & & $40-60$ & 0.189 \\
4. & Land & Forest & -0.610 \\
5. & use & Agricultural & -0.983 \\
6. & & land & -0.997 \\
\hline
\end{tabular}

*Correlation is significant at 0.05 level.

Mean total carbon stock: The mean total soil organic carbon $\left(\mathrm{MT}_{\mathrm{soc}}\right)$ values for forest, agricultural and barren land were $98 \mathrm{t} \mathrm{ha}^{-1}, 36.6 \mathrm{t} \mathrm{ha}^{-1}$ and $83.6 \mathrm{t} \mathrm{ha}^{-1}$ respectively, i.e. the mean total carbon stock followed the order as forest $>$ barren land $>$ agricultural land.

Mean SOC in terms of $\mathrm{CO}_{2}$ equivalents: Mean SOC in terms of $\mathrm{CO}_{2}$ equivalents $\left(\mathrm{C}_{\text {soc }}\right)$ for forest, agricultural and barren land ranged from 183.5 to 80.74 $\mathrm{CO}_{2}$-e ha-1, 79.27 to $22.02 \mathrm{CO}_{2}$-e ha-1 and 121.11 to $80.74 \mathrm{CO}_{2}$-e ha ${ }^{-1}$ for $0-20 \mathrm{~cm}$ to $40-60 \mathrm{~cm}$ soil depth respectively (Fig. 2). These are the amounts of $\mathrm{CO}_{2}$ gas molecules sequestered by these land study areas from its surrounding atmosphere in the form of soil organic carbon. SOC values in terms of $\mathrm{CO}_{2}$ equivalents help in understanding of SOC relation with $\mathrm{CO}_{2}$ gas. This is the environmental perspective which includes the removal of $\mathrm{CO}_{2}$ from the atmosphere, the improvement of soil quality, and the increase in biodiversity (Batjes \& Sombroek 1997).

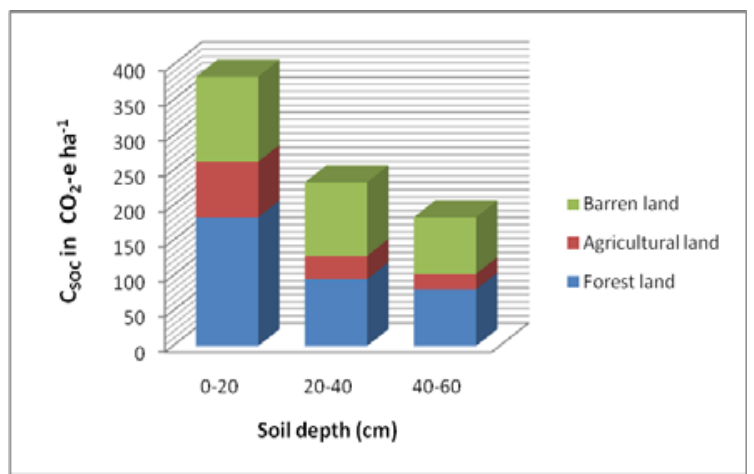

Fig. 2. Mean $\mathrm{SOC}$ in terms of $\mathrm{CO}_{2}$ equivalents $\left(\mathrm{CO}_{2}\right.$-e ha- $)$

In order to understand soil C composition changes among three land-use sites in the study area, one assumption was that any differences in the measured properties were the result of land use effects. The maximum carbon stock was present in forest soil. The higher percent of soil organic carbon in forest may be due to dense canopy and higher input of litter which results in maximum storage of carbon stock. Organic matter has been lost from the cropland mainly through ploughing, which makes soil more likely to erode. Minimizing erosion is an important step to reversing the loss and building soil quality, which usually requires leaving residue on the surface or planting a cover crop. Some land use practices (such as lowtillage, legume based or manure application agriculture) can increase soil C storage.

\section{Acknowledgements}

We express our gratitude to Prof. Kedar Rijal, head of Central Department of Environmental Science and Mr. Jagannath Aryal, lecture of Central Department of Environmental Science for providing opportunity and valuable comments to do this work. We also gratefully acknowledge the Central Department of Environmental Science, TU Kirtipur for providing us laboratory facilities. We would like to thank our friends who helped us during this work. 


\section{References}

Bajracharya, R.M., R. Lal and J.M. Kimble. 1998. Long term tillage effect on soil organic distribution in aggregates and primary particle fractions of two Ohio soils. In: Management of carbon sequestration in soil. (Eds. R. Lal , J.M. Kimble, R.F. Follett and B.A. Stewart), CRC Press, Boca Raton, FL, USA. pp. 113-123.

Batjes, N.H. and W.G. Sombroek. 1997. Possibilities for carbon sequestration in tropical and subtropical soils. Global Change Biology 3:161-173.

Blake, G.R. and K.H. Hartege. 1986. Bulk density. In: Physical and mineralogical methods of agronomy, methods of soil Analysis, (Ed. A.L. Page), part 1. $2^{\text {nd }}$ ed. monographs. ASA; SSSA. Maidson, W1, pp. 425-442.

Brady, N.C. 1999. The nature and properties of soil. $13^{\text {th }}$ ed. Macmillan Publishing Company, U.S.A.

Drinkwater, L.E., P. Wagoner and M. Sarrantonio. 1998. Legume-based cropping systems have reduced carbon and nitrogen losses. Nature 396: 262-265.

IPCC 2000. Special report on land use, land-use change and forestry. Intergovernmental Panel on Climate Change, Cambridge university press, Cambridge, UK.

IPCC 2003. Good Practices Guidance for Land Use, LandUse change and Forestry. Institute for Global Environmental Strategies (IGES) for the Intergovernmental Panel on Climate Change (IPCC), Kanagawa, Japan.

Lal, R. 2001. Soil degradation by erosion. Land Degrad Develop 12 (6):519-539.

Lal, R. 2004. Soil carbon sequestration to mitigate climate change. Geoderma, 123:1-24

Lal, R., J. M. Kimble and B.A. Stewart. 1998. Land use and C pools in terrestrial ecosystems, In: Management of Carbon Sequestration in Soil. (Eds. R. Lal, B.A. Stewart) CRC Press, Boca Raton, Fl, USA. pp. 1-10.
Liefeld, J., S. Bassin and J. Fuhrer. 2005. Carbon stock in Swiss agriculture soils predicted by land use soil characteristics and altitude. Agriculture, Ecosystem and Environment 105: 225-266.

Metting, F.B., J.L. Smith and J.S. Amthor. 1998. Science needs and new technology for soil carbon sequestration. In: Carbon Sequestration in Soils: Science, Monitoring and Beyond, Proceeding of the St. Michaels Workshop. (Eds. N.J. Rosenberg, R.C. Izaurralde and E.L. Malone pp.1-34.

Morisada, K.., K. Ono and H. Kanomata. 2004. Organic carbon stock in forest soils in Japan. Geoderma 119:21-32.

Paustian, K.., O. Andren, H. Janzen, R. Lal, P. Smith, G. Tian, H. Tiessen, N.M. Van and Woomer P. 1997. Agricultural soil as a $\mathrm{C}$ sink to offset $\mathrm{CO}^{2}$ emissions. Soil use mange 13:230-244.

Pearson, T.R.H., S. Brown and N.H. Ravindranath. 2005. Integrating carbon benefit estimates into GEF projects. Capacity development and adaptation group 41 guidelines, UNDP Global Environment Facility, Bureau of development policy, New York, USA.

Pearson, T.R., S.L. Brown and R.A. Birdsey. 2007. Measurement guidelines for the sequestration of forest carbon. General technical report, USDA forest service.

Schlesinger, WH. 1997. Biogeochemistry: an analysis of global change. $2^{\text {nd }}$ ed. San Diego: Academic Press.

Shrestha, B.M. 2002. Land Use effect on Soil Carbon Sequestration and Greenhouse Gases Flux in a mountainous Watershed of Nepal. Noragric M.Sc. Thesis. Agricultural University of Norway, Norway.

Walkley and I.A. Black. 1934. An examination of Degtjareff method for determining soil organic matter and a proposed modification of the Chromic Acid titration method. Soil Science 37: 29-37. 
Nepal Journal of Science and Technology Vol. 14, No. 2 (2013) 103-108 